\title{
Variability of diatom community composition and structure in mountain streams
}

\author{
Lorena González-Paz (ib) María Comesaña • Isabel Pardo · José Barquín • \\ Alejandra Goldenberg-Vilar · Cristina Delgado
}

Received: 14 June 2021 / Revised: 29 November 2021/ Accepted: 30 November 2021/Published online: 16 December 2021

(C) The Author(s) 2021

\begin{abstract}
Small rivers support high levels of biodiversity, being especially sensitive to the effects of global change. Temporal records of community composition in minimally impaired streams can be used to explore trends in biodiversity in response to climate change and natural temporal variation. We approached the comparison of two time periods (2003-2008 and 2016-2020) to study whether the composition of diatom assemblages changed over time in twentythree streams of the mountain range of Picos de Europa (Northern Spain). The stream's water chemistry indicated significant decreases in $\mathrm{N}_{-} \mathrm{NO}_{3}{ }^{-}$and $\mathrm{P}_{-} \mathrm{PO}_{4}{ }^{3-}$ content over time. In these minimally disturbed streams, the specific diatom community was dominated by Achnanthidium pyrenaicum, Achnanthidium minutissimum and Cocconeis euglypta.
\end{abstract}

Handling editor: Judit Padisák

Supplementary Information The online version contains supplementary material available at https://doi.org/10.1007/ s10750-021-04779-4.

L. González-Paz $(\bowtie) \cdot$ M. Comesaña .

I. Pardo · C. Delgado

Universidade de Vigo, Departamento de Ecoloxía e

Bioloxía Animal, 36310 Vigo, España

e-mail: logonzalez@uvigo.es

J. Barquín · A. Goldenberg-Vilar

IHCantabria - Instituto de Hidráulica Ambiental de la Universidad de Cantabria, Universidad de Cantabria,

Santander, Spain
PERMANOVA analyses did not identify significant changes in diatom assemblage composition between periods or river types. Diatom indices (e.g. IPS, NORTIdiat) indicated high or good ecological status and relatively high alpha diversity values were found in these mountain rivers during the studied years. Although diversity and evenness showed a significant decrease over time, the temporal stability of the rivertype diatom reference community between the two periods should be considered as an indicator of biodiversity persistence of high importance when monitoring the ecological status following the reference condition approach.

Keywords Biodiversity - Conservation · Microalgae $\cdot$ Reference condition - Small rivers · Spain

\section{Introduction}

One of the most important global challenges of the twenty-first century is to maintain the benefits that aquatic ecosystems bring to humans without affecting aquatic biodiversity and fundamental ecosystem processes (Pawlowski et al., 2018). To achieve this, extensive national and international regulations have been adopted to protect water resources all over the world, such as the European Union Water Framework Directive (WFD-European Commission 2000/60/ 
EC). Since WFD was implemented in Europe, it has provided an economic, social, and environmental approach to the sustainable exploitation of water bodies based on the protection of their biological and chemical quality at local, regional, national, and European levels (Cruz et al., 2010; Mortágua et al., 2019). This regulation requires that all water bodies including estuaries, coastal waters, rivers, lakes, and groundwaters reach the "good ecological status" at ambitious deadlines (Hering et al., 2018). In streams and rivers, aquatic organisms used as biological quality elements are benthic macroinvertebrates, macrophytes, phytobenthos and fish (WFD-European Commission 2000/60/EC, Karaouzas et al., 2019). Specifically, phytobenthos and invertebrates are the most widely used in rivers to assess anthropogenic pressures, due to their sensitivity to different types of stressors and their integration of pressures at different scales of time (Birk et al., 2012).

Diatoms constitute a dominant and diverse algae group in aquatic ecosystems, playing a key role in primary production, as well as in the silica cycle (Burliga \& Kociolek, 2016). Its importance increases especially in small streams, where diatoms constitute the predominant primary producer component (Kireta et al., 2012); therefore, affecting changes in the structure and functioning of diatom communities to entire ecosystems (Peszek et al., 2021). They have been the subject of studies relating their response to anthropogenic stressors, nutrient enrichment, pollutant episodes (e.g. oil spills) and to already observed effects of climate change (Jiang et al., 2014; Polmear et al., 2015). Many are the physico-chemical alterations attributed to global change (e.g. increase in temperature, eutrophication; Jiang et al., 2014; Raimonet et al., 2018), being closely related to long-term changes in diatom communities (Jiang et al., 2014). Results up-to-date evidence that time series on biotic and abiotic data are useful in the analysis of long-term responses of individual species to the temporal variation of environmental conditions (Schlüter et al., 2012). However, not many studies have aimed to understand the natural variability that exists in diatom communities inhabiting minimally disturbed streams (Rott et al., 2006; Stoddard et al., 2006; Novais et al., 2020) or reference streams (Cantonati et al., 2020; Peszek et al., 2021; Rimet et al., 2004).

The reference conditions of WFD are established following specific and objective criteria and rules on the accepted level of human pressures to select a spatial network of minimally disturbed sites (Pardo et al., 2011, 2012). In fact, finding common approaches to define criteria for reference conditions was one of the great challenges of the WFD. The "biological reference condition" is based on measurements of biological parameters sampled at nonimpacted sites having minimum levels of anthropogenic pressure (Nõges et al., 2009). The reference conditions cannot be considered static but change because of the impacts of climate change on the physical and chemical conditions of water bodies (Nõges et al., 2007). Given that the effects of climate change can cause changes in the ecosystems at reference conditions, Nõges et al. (2009) stated that the WFD should re-evaluate the reference conditions according to the observed changes, using monitoring networks of potential reference sites or modelling tools that allow distinguishing the effects of climate change. Consequently, restoration objectives (i.e. good ecological status) should also be periodically assessed accepting that some changes (e.g. loss or changes in the distribution of some species) have become permanent.

The "biological reference condition" is linked to each stream type and type specific reference sites must present the full range of conditions expected to occur naturally in each stream type (Sánchez-Montoya et al., 2012; Stoddard et al., 2006). Streams and rivers of similar environmental and hydromorphological conditions and inhabited by the type of specific biological communities are classified within the same "type". Following WFD, river types are first differentiated by abiotic descriptors (e.g. altitude, catchment area, geology) and secondly, stream types are confirmed with their biological communities. Many reference sites correspond to small streams in nature-preserved areas where streams and rivers tend to be in good ecological status. As the water temperature has generally close values to that of groundwater at the source in headwater streams (Caissie, 2006) there are ideal study cases to understand ecological responses to water temperature gradients (Arai et al., 2015; Delgado et al., 2020). The study of headwater's biological communities should allow us to understand how climate change can affect freshwater ecosystems (Nukazawa et al., 2018). Despite that headwater streams represent $>70 \%$ of the total river network length (Kuglerová et al 2017) they have been 
understudied since they are usually not included in water management due to their small size (Stubbington et al., 2017). Nevertheless, they constitute valued water resources and they are also very important because of their ecological processes, such as sources of migrants, reservoirs of biodiversity or nutrient absorption and retention (Hlúbiková et al., 2014; Peterson et al., 2001). These headwaters are particularly vulnerable to changes in land-use and pollutants from diffuse sources, as they have a greater contribution of watershed area to stream area compared with larger streams (Selby et al., 1985). Different land-uses nearby headwater streams have repercussions on water physical and chemical variables (e.g. variations in conductivity levels and nutrient content; Pérez et al., 2013), but also on the structure of biological communities (e.g. diatoms and invertebrates; Hlúbiková et al., 2014; Moore \& Palmer, 2005).

Conservation of mountain streams diversity is believed to be most effective when management focuses on restoring or conserving environmental conditions at various points within relatively small watersheds (Göthe et al., 2014). Although, major efforts on biodiversity conservation are usually directed towards large size species, such as mammals or vertebrates (e.g. Grenyer et al., 2006), few studies dealt with diatom conservation status valued by the risk of species to disappear from an area (Falasco \& Bona, 2011; Lange-Bertalot \& Steindorf, 1996).

Climate change has caused in Spain in recent decades a 6-32\% reduction in rainfall, an increase of $1.5-3.3^{\circ} \mathrm{C}$ in temperature and a $2-54 \%$ reduction in water resources (Senent-Aparicio et al., 2017). The frequency of warm summers has increased in the Picos de Europa National Park (Serrano et al., 2011) and the effects of climate change are expected to worsen in the near future (Pérez-Sánchez et al., 2020). However, in recent years this National Park has experienced a reduction in agricultural practices and an expansion of forest area (García-Llamas et al., 2019). Therefore, we aimed to test whether diatom assemblages changed over time in well-preserved mountain streams. We used data from diatom samples and environmental variables from streams in a mountainous protected area in the Cantabrian Cordillera, Northern Spain. Samples were collected throughout two periods spanning the last 17 years (2003-2008 and 2016-2020). Our working hypotheses are as follows: (i) the low variability of diatom communities over time during the two studied periods, since the mountain streams studied are located in a well-preserved area; (ii) the absence of differences in diatom composition amongst Spanish-established river types; and (iii) the maintenance of high/good ecological status over time according to diatom indices (e.g. diversity, IPS index (Cemagref, 1982) and NORTIdiat index (Pardo et al., 2018)).

\section{Materials and methods}

Study area

The study area is in the Picos de Europa National Park (N Spain; Fig. 1). This is a high mountainous area up to $2,650 \mathrm{~m}$ above sea level (m. a. s. 1.) located in the northern slope of the Cantabrian Mountains (Ballesteros et al., 2020). The Park has been a UNESCO biosphere reserve since 2003 and it is part of the Natura 2000 network. The climate is humid and temperate with cool summers and no dry season (Ballesteros et al., 2020), with averaged rainfall being approximately $1500 \mathrm{~mm}$, with temperatures ranging between -3 and $17{ }^{\circ} \mathrm{C}$ and with snow covering the territory above the $1500 \mathrm{~m}$ for 6 months a year (Ballesteros et al., 2020; Elicisimo, 1990). The substrate is mostly limestone, with well-developed karst and with glacial debris (Canseco \& Heredia, 2003). The information on land-use activities was estimated from CORINE land cover maps (Bossard et al., 2000; Coordination of Information on the Environment, Land Cover 2000). The land-use activities did not experience remarkable changes over time in this protected area, although it seems that agriculture has decline over the last decade (Perpiña-Castillo et al., 2020). All the points showed between 85 and $100 \%$ of natural and semi-natural areas and between 0 and $15 \%$ of agricultural areas. The most common riparian species in these Cantabrian Mountains are Castanea sativa Mill., Fagus sylvatica L. and Pinus sylvestris $\mathrm{L}$., which are widely distributed in the north of the Iberian Peninsula (José Vidal-Macua et al., 2017; Nunes et al., 2020). The most frequent understorey species were Plantago lanceolata L., Trifolium pratense L. and Trifolium repens L. (Prince et al., 2012).

Biotic groups that include meiofauna and diatoms are poorly studied in headwaters (Stubbington et al., 


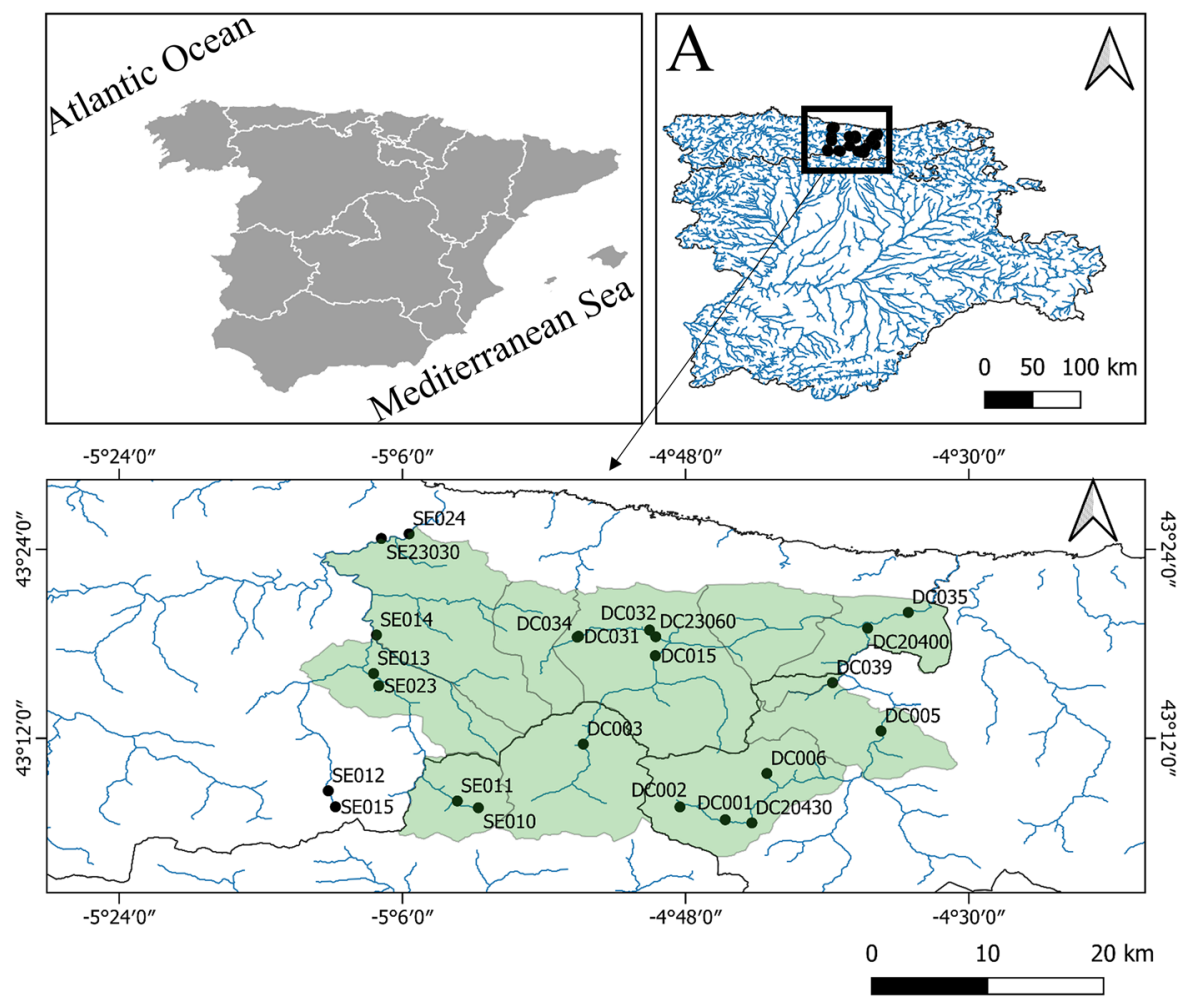

Fig. 1 Map of the study area in the Cantabrian region of Spain locating the 23 sampling sites $(n=46)$ in the Sella (SE codes), Deva and Cares rivers (DC codes). The Picos de Europa National Park has been highlighted in green

2017). Although studies on hydrology (ÁlvarezCabria et al., 2016; Belmar et al., 2016) and on fish and invertebrates (Álvarez-Cabria et al., 2017; Estevez et al., 2017) have been conducted in Picos de Europa National Park, information on the diatom communities inhabiting this study area is still scarce. The river network comprises three main river basins: Sella, Deva and its tributary the Cares, together with their small tributaries, being the main component of flow directed to the North. These rivers cover an altitudinal range between 100 and 1000 m.a.s.l., highlighting the existence of river canyons, such as the Cares (Ballesteros et al., 2019; Meléndez et al., 2019). These streams are located within the Spanish provinces of Asturias, Cantabria and León. The Sella River has a length of $66 \mathrm{~km}$ before draining into the Cantabrian Sea and a catchment area of $1246 \mathrm{~km}^{2}$ (Nicola et al., 2018). Its average flow is $18.2 \mathrm{~m}^{3} \mathrm{~s}^{-1}$ with annual fluctuations between 9.1 and $36.6 \mathrm{~m}^{3} \mathrm{~s}^{-1}$ (CEDEX, 2018a). Whereas the Deva river has a length of $64 \mathrm{~km}$ and a catchment area of $1184 \mathrm{~km}^{2}$. Its interannual average flow is $14.4 \mathrm{~m}^{3} \mathrm{~s}^{-1}$, ranging between 5.4 and $29.3 \mathrm{~m}^{3} \mathrm{~s}^{-1}$ (CEDEX, 2018b). Its main tributary, the Cares River has a catchment area of $495 \mathrm{~km}^{2}$ (Rodríguez-Castillo et al., 2019). The studied streams are within the National Park, except for 2 sites located in a nearby spring fed stream (Fig. 1). A total of 23 stream sites were sampled in different years comprising two time periods: 2003-2008 $(n=23$ samples) and 2016-2020 ( $n=23$ samples; Fig. 1; map developed using QGIS v.3.12.2).

\section{River typology}

According to the WFD, the ecological assessment of biological communities has to be 'type specific', i.e. water bodies should be grouped according to their physical, biological and morphological attributes. River types can be defined using two different WFD systems: System A is a standardised system with physical descriptors and mandatory limits, whereas System B is more flexible and allows the inclusion of mandatory and optional variables and limits (WFD 2000/60/EC). Spanish rivers are classified according 
to a System B typology based on physico-chemical descriptors, accordingly, within the Picos de Europa National Park; the rivers are divided into six different Spanish types (Table 1; RD 817/2015; ARM/2656/ 2008). On the other hand, the predictive diatom-based model NORTIdiat developed by Pardo et al. (2018) established river types based on their diatom communities in reference sites and then used mandatory and optional descriptors of the WFD typology to environmentally characterise them, corresponding to a typology B of 4 river types that represented existing gradients in calcareous geology, basin size and slope along the whole North of Spain (From Galicia to the Basque Country). The resulting river types were named accordingly: Type 1, calcareous mountain rivers; Type 2, main river axes; Type 3, siliceous rivers; and Type 4, mixed rivers. According to this typology, all streams analysed in this study correspond to Type 1, calcareous mountain rivers (Pardo et al., 2018).

\section{Diatom sampling}

A total of 46 diatom samples and corresponding environmental variables were collected at 23 sampling sites established along the Sella, Deva and Cares rivers during the summer (June-September) of 2003 $(n=14), 2004(n=3), 2008(n=6), 2016(n=1)$, $2017(n=1), 2018(n=6), 2019(n=11)$ and 2020 $(n=4) .14$ out of 23 sampling sites studied were sampled in both periods. Between 2008 and 2016 no samples were collected. The sampling period and Spanish-type correspondence (Spanish typology) of the 46 samples are described in Table 1. These 46 samples belong to the monitoring network established in the implementation of the Water Framework Directive (WFD 2000/60/EC) and they were not collected on a regular basis every year. For this reason, some river types had more representation in one period than in the other (e.g. R-T32 type overrepresented in the 1 st period and R-T22 in the 2nd; Table 1).

Water and diatom samples were collected from stones by brushing the top surface of each with a toothbrush, following the European standards (AFNOR, 2003; CEN, 2004; Kelly et al., 1998) and preserved with formaldehyde solution (37\%) immediately after the collection. Then, an aliquot of 1 to $3 \mathrm{ml}$ from each sample was treated with a $65 \%$ solution of nitric acid $\left(\mathrm{HNO}_{3}\right)$ and potassium dichromate $\left(\mathrm{K}_{2} \mathrm{Cr}_{2} \mathrm{O}_{7}\right)$ at room temperature for $24-48 \mathrm{~h}$ to remove the organic content. The acid residues were removed by centrifugation (1500 rpm), followed by rinsing with distilled water. After the oxidation, permanent slides were prepared with Naphrax ${ }^{\circledR}$. Diatoms were studied under the light microscope (Olympus BX40), where a minimum of 400 diatom valves were counted on each slide and were identified to the lowest possible taxonomic level. The identification was based on Krammer \& Lange-Bertalot (1986, 1988, 1991a, b), Krammer (1997a, b, 2002), Lange-Bertalot (1993; 2001), Prygiel \& Coste (2000), Trobajo et al. (2013), Wetzel et al. (2015) and LangeBertalot et al. (2017). Names were updated according to Algaebase (Guiry \& Guiry, 2021).

\section{Data analysis}

Diatoms were collected in parallel to environmental variables, except for the years 2003 and 2020, for which no environmental data are available. An environmental variable sample matrix was produced and grouped by periods: the 2004-2008 samples corresponding to the 1st period and the 2016-2019 samples to the 2 nd. The environmental matrix consisted of five variables: electrolytic conductivity $(\mu \mathrm{S}$
Table 1 Samples collected (n) per period and per Spanish river type in streams flowing through Picos de Europa (RD 817/2015)

\begin{tabular}{|c|c|c|}
\hline \multicolumn{2}{|l|}{ Samples $(n)$} & \multirow[b]{2}{*}{ River types } \\
\hline $\begin{array}{l}\text { 1st period } \\
(2003-2008)\end{array}$ & $\begin{array}{l}\text { 2nd period } \\
(2016-2020)\end{array}$ & \\
\hline 2 & 5 & R-T21-Siliceous Cantabrian-Atlantic Rivers \\
\hline 1 & 7 & R-T22-Calcareous Cantabrian-Atlantic rivers \\
\hline 4 & 8 & R-T26-Calcareous wet mountain rivers \\
\hline 6 & 4 & R-T29-Main Cantabrian-Atlantic calcareous river networks \\
\hline 9 & 0 & R-T32-Small Cantabrian-Atlantic calcareous networks \\
\hline
\end{tabular}


$\left.\mathrm{cm}^{-1} ; n=27\right), \mathrm{pH}(n=25)$, oxygen saturation $(\%$; $n=14)$, nitrogen nitrate (mg $\left.\mathrm{N}_{-} \mathrm{NO}_{3}{ }^{-} \mathrm{L}^{-1} ; n=28\right)$ and phosphorus phosphate (mg $\mathrm{P}_{-} \mathrm{PO}_{4}{ }^{3-} \mathrm{L}^{-1}$; $n=24)$. Although data on water temperature were not available, it is known that the average values in this area present temperatures between 2.5 and $11{ }^{\circ} \mathrm{C}$ (Meléndez, et al., 2019). Electrolytic conductivity and oxygen saturation were determined in situ using a Hanna Instruments HI9829 multiparameter probe. $\mathrm{N}_{-} \mathrm{NO}_{3}{ }^{-}$and $\mathrm{P} \_\mathrm{PO}_{4}{ }^{3-}$ were measured with an AutoAnalyzer 3 (Bran + Luebbe, Germany). Normality was checked with the Shapiro test and student's $t$ test was used to compare both periods. These analyses were performed using SPSS v.24 statistical software. The level of significance for the test was set as $P<0.05$. The values of the physical and chemical variables measured per site were compared with each variable boundary established for the classification of the ecological status classes of the corresponding river type defined in the Spanish normative (RD 817/2015). The most correlated environmental variables (Spearman's Rank correlation $>0.6$ ) were eliminated, and variables with several representative data for both periods were selected and fourth root transformed. Diatom abundances were $\log (x+1)$ transformed before Bray-Curtis similarity matrices were calculated. Then, a Distance-based linear model (DistLM; Legendre and Anderson, 1999; McArdle and Anderson, 2001) in combination with distance-based redundancy analysis (dbRDA) (Anderson et al., 2008) were used to identify the set of environmental variables that best explained diatoms distribution amongst samples. The best-fit model, based on Akaike's Corrected Information Criterion (AICc; Akaike, 1987) was selected and visualised using dbRDA ordination.

A permutation analysis of variance (PERMANOVA; McCune et al., 2002) was used on BrayCurtis similarity matrix with 9999 permutations to test whether diatom assemblages varied across river basins, periods, river types and ecological status classes calculated with NORTIdiat and IPS. Nonmetric multidimensional scaling (nMDS) was used to summarise the variability of the two periods in terms of diatom community structure based on Bray-Curtis dissimilarity distance. All multivariate analyses were conducted in PRIMER7 v.7 software (Clarke \& Gorley, 2015) with the PERMANOVA + add-on package (Anderson et al., 2008). Student's $t$ test was applied to establish the statistical significance of the difference between both periods of the abundances of the species belonging to the reference community. The level of significance for the test was set as $P<0.05$.

Finally, a SIMPER analysis (SIMilarity PERcentage; cut-off 90\%) was performed using the PRIMER v.7 software to assess the degree of similarity between the diatom assemblages amongst periods, river types and ecological status calculated with NORTIdiat and with the IPS. The most common diatom indices in Europe (e.g. IBD, CEE, IDAP) together with the Specific Polluosensitivity Index (IPS, Cemagref, 1982), the Shannon Diversity Index, the corresponding evenness and the Trophic Diatom Index (TDI, Kelly \& Whitton, 1995) were calculated with the Omnidia software v 5.3 (Lecointe et al., 2003). The scale of most diatom index values is from 0 to 20 , except for TDI that is scaled from 1 to 100 . The NORTIdiat index was calculated by applying the Bray-Curtis similarity to the matrix of the relative abundances of log-transformed samples based on the diatom reference community of river Type 1 (calcareous mountain rivers) (Pardo et al., 2018). The IPS and the NORTIdiat were used to calculate the ecological status class of each test sample. IPS values above 17 suggest a high ecological status, whilst IPS between 15 and 17 implies a good ecological status (Noga et al., 2014). NORTIdiat values above 0.930 suggest a high ecological status and values between 0.930 and 0.700 imply a good ecological status (Pardo et al., 2014, 2018). Data were Box-Cox transformed when required to meet the requirements of normal distribution (Shapiro-Wilk's test). Student's $t$ test was performed to verify significant differences in diatom indices between the two periods studied and the two river basins (Sella and Deva-Cares rivers). The level of significance for the test was set as $P<0.05$.

\section{Results}

Physical and chemical variables

The average electrolytic conductivity (EC) values decreased over time, from $262.0 \mu \mathrm{S} \mathrm{cm}^{-1}$ in the 2004-2008 period to $222.9 \mu \mathrm{S} \mathrm{cm}^{-1}$ during the 2016-2019 period. The $\mathrm{pH}$ values significantly $(P=0.000)$ increased with time from 7.7 to 8.4 . The oxygen saturation was slightly higher during the 2 nd period, with averages from 91.7 to $97.8 \%$ (Fig. 2). 
Since we do not have dissolved oxygen data for all samples, it could not be included in the analyses, but the values range was between 8.44 and $11.05 \mathrm{mg}^{-1}$.
Nitrogen nitrate ( $\mathrm{N} \_\mathrm{NO}_{3}{ }^{-}$) and phosphorus phosphate contents $\left(\mathrm{P}_{-} \mathrm{PO}_{4}{ }^{3-}\right)$ were significantly $(P=0.000$ and $P=0.015$, respectively) lower during the 2 nd period
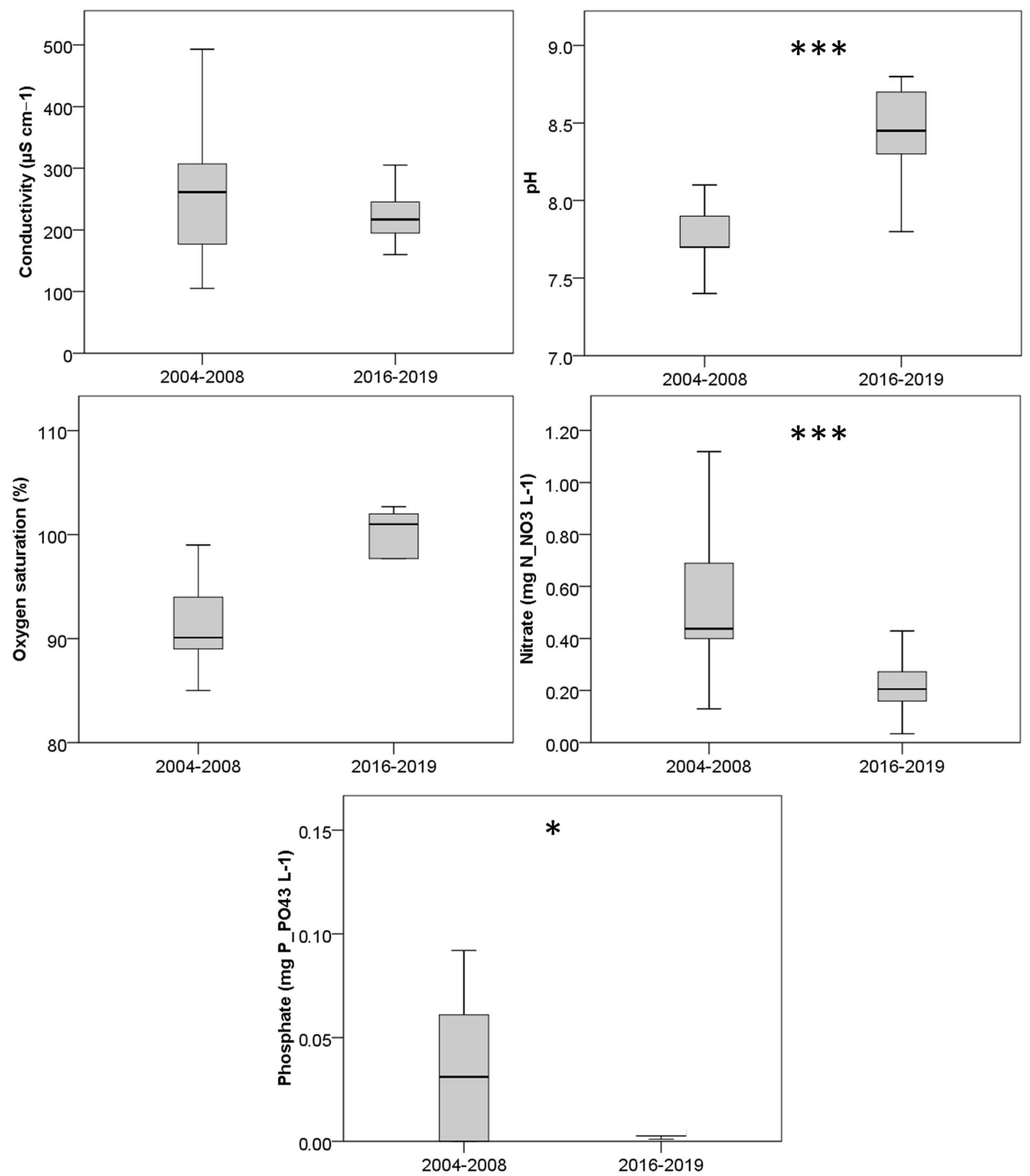

Fig. 2 Boxplots of the four physical and chemical variables studied in both periods. The median values (central line), 25th and 75th percentile values (box) and the error bars are shown. Test with * significant at the 0.05 level and *** at the 0.001 level 
(Fig. 2). The DistLM analysis indicated that the bestfit model explaining diatom's distribution was composed of all the environmental variables (multiple $\mathrm{R}^{2}=0.28$ ). The $\mathrm{pH}$ was positively correlated with the EC; thus, it was eliminated from the analysis. First two dbRDA axes explained $79.8 \%$ of fitted model variation (Fig. 3). The dbRDA1 explained 57.2\% and separated samples from the first period with high levels of conductivity towards its positive part, from samples from the second period with low levels of conductivity on its negative end. The second axis (dbRDA2) explained $22.6 \%$ of the total variance and separate high nutrient content streams towards its positive part, from low nutrient content streams on its negative side (Fig. 3).

\section{Analyses of diatom assemblages}

The resulting diatom matrix consisted of 46 samples and a total of 132 diatom taxa (Supplementary material 1). PERMANOVA showed that there were no significant differences between diatom assemblages regardless of the river basin, Sella vs DevaCares (pseudo- $F_{1,42}=1.65, P=0.055$ ). Although the nMDS ordination showed a slight grouping of the samples corresponding to the two studied periods (Fig. 4), the composition of diatom assemblages between the study periods was not significantly different either ( seudo- $F_{1,42}=3.35, P=0.164$ ).

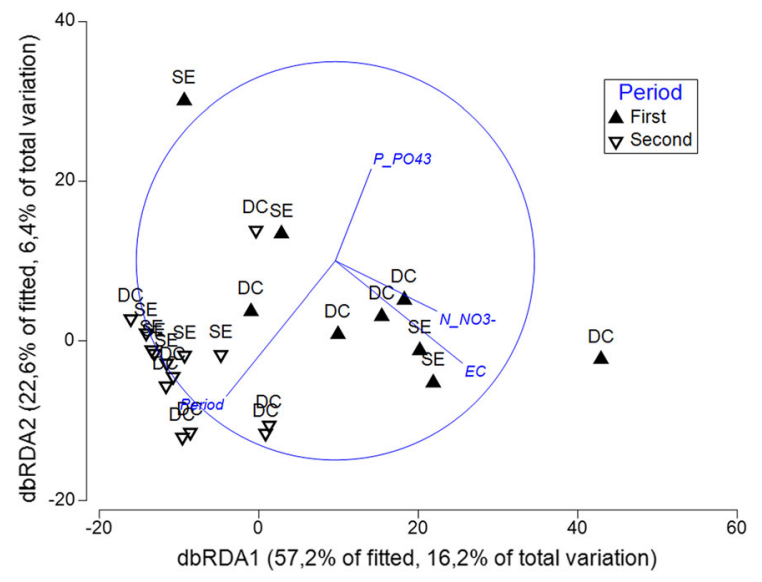

Fig. 3 Distance-based redundancy analysis on diatom communities. Colours representing the period: first (2003-2008) and second (2016-2020). DC labels represent Deva-Cares samples; SE represent Sella samples

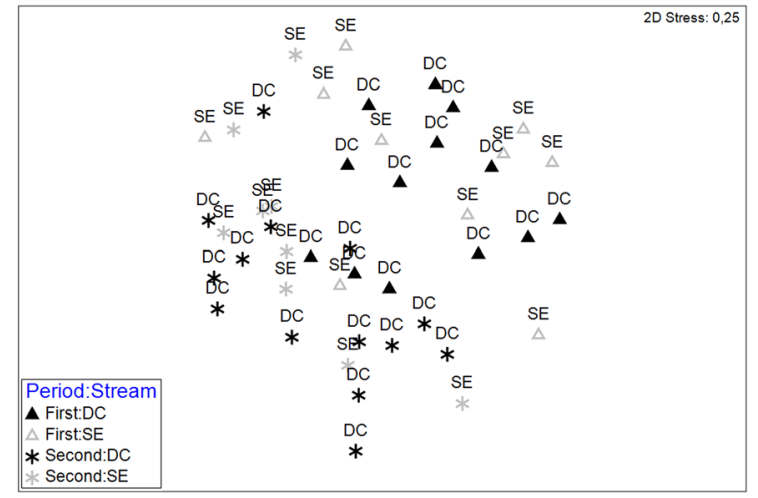

Fig. 4 Non-metric MultiDimensional Scaling (nMDS) analysis of benthic diatom samples. Symbols represent the studied periods: triangle, first period and asterisk, second period. Colours represent the studied stream: black, Deva-Cares (DC) and grey, Sella (SE). Bray-Curtis distance, stress 0.25

The most abundant species in this study area were Achnanthidium pyrenaicum (Hustedt) Kobayasi (34.9\% average abundance), Cocconeis euglypta Ehrenberg (10.4\%), Achnanthidium minutissimum (Kützing) Czarnecki (9.4\%), Achnanthidium atomoides Monnier, Lange-Bertalot \& Ector (6.3\%), Cocconeis lineata Ehrenberg (5.9\%), Nitzschia fonticola (Grunow) Grunow (4.9\%), Cocconeis pseudolineata (Geitler) Lange-Bertalot (3.6\%) and Amphora pediculus (Kützing) Grunow (2.2\%). SIMPER analysis showed that $\sim 90 \%$ of the cumulative dissimilarity between the Bray-Curtis groups for the studied periods was owed to 64 taxa and the average dissimilarity was $59.6 \%$ between the two periods. The species that contributed the most to assemblage dissimilarity between both periods were Nitzschia fonticola, Cocconeis lineata and Achnanthidium atomoides (Fig. 5A, B), with ca. 5.0\%, 4.6\% and 4.6\%, respectively. The within group average similarity were $45.5 \%$ and $46.3 \%$ for period 1 and period 2, respectively. The greatest contribution to the similarities for both periods was provided by the most abundant species Achnanthidium pyrenaicum (18.9\% and $27.9 \%$, in the 1 st and in the 2 nd period, respectively), Achnanthidium minutissimum sensu lato $(12.4 \%$ and $16.7 \%$, respectively) and Cocconeis euglypta $(12.1 \%$ and $12.7 \%$, respectively; Fig. 5A, B). In general, the observed variations were very small between periods for both ecological status classes. In the high ecological status $(n=11)$, Student's $t$ test did not find significant differences for the reference community 
(A) High ecological status

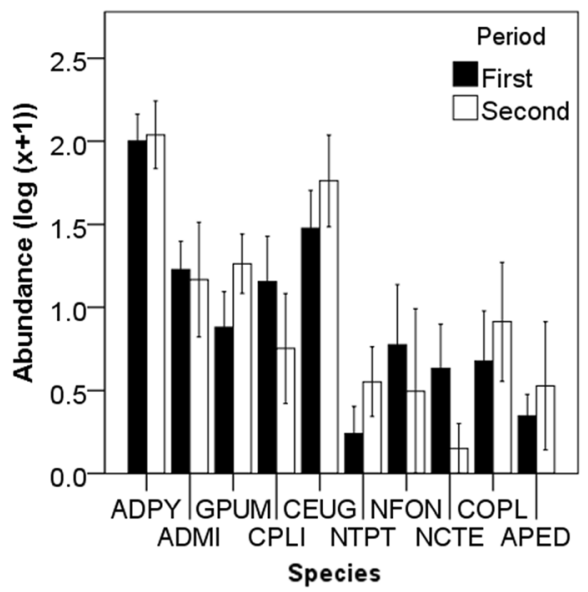

Fig. $5 \log (x+1)$-transformed average abundances of the dominant species for high (A) and good (B) ecological status (NORTIdiat classes) in both periods: 1st (2003-2008) and 2nd (2016-2020). ADPY, Achnanthidium pyrenaicum; ADMI, Achnanthidium minutissimum; GPUM, Gomphonema pumilum; CPLI, Cocconeis lineata; CEUG, Cocconeis euglypta; NTPT,

species between periods. However, significant differences $(P<0.05)$ were found for the species Achnanthidium pyrenaicum, Cocconeis lineata, Nitzschia fonticola and Navicula cryptotenella Lange-Bertalot between periods for the samples classified as good ecological status $(n=35)$.

Significant differences in diatom assemblages amongst river types (according to the official Spanish typology) were not found (PERMANOVA, pseudo$\left.F_{4,31}=1.42, P=0.23\right)$. Moreover, nMDS ordination did not show a clear separation of samples amongst river types, instead, a dispersed distribution was observed in river type's samples (Fig. 6A, B). The SIMPER analysis indicated that the within group average similarity for each type ranged between 43.9 and $49.0 \%$ and the average dissimilarities amongst types ranged between 52.7 and $61.6 \%$. The highest dissimilarities were found when comparing the R-T29 type with the R-T26 and R-T21 types. In both cases, the species that contributed the most to this dissimilarity were Achnanthidium atomoides and Cocconeis lineata.

The result of the diatom indices (IPS or NORTIdiat) indicate that all samples belong to good or high ecological status. PERMANOVA showed that there were no significant differences between the diatom assemblages regardless of the ecological status
(B) Good ecological status

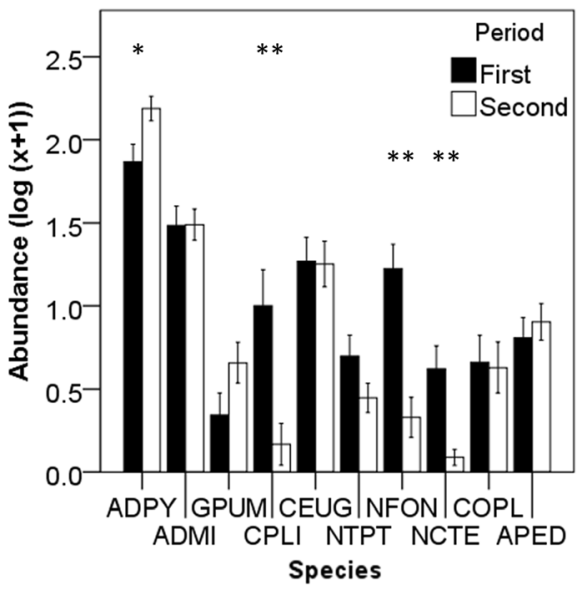

Navicula tripunctata; NFON, Nitzschia fonticola; NCTE, Navicula cryptotenella; COPL, Cocconeis pseudolineata; APED, Amphora pediculus. Error bars represent $\pm 1 \mathrm{SE}$ (Standard Error). Test with * significant at the 0.05 level and ** at the 0.01 level

calculated with the NORTIdiat (PERMANOVA, pseudo- $\left.F_{1,39}=1.52, P=0.08\right)$ or with the IPS (PERMANOVA, pseudo- $F_{1,39}=1.48, \quad P=0.09$ ). Thus, no segregation of samples was observed (Fig. 6A, B). It should be noted that many of the samples classified as in good ecological status by NORTIdiat (Fig. 6A) were classified in high ecological status by IPS (Fig. 6B). The SIMPER analysis showed that the dissimilarity between "good" and "high" ecological status was $56.9 \%$ for NORTIdiat and $58.1 \%$ for IPS.

Diatom diversity and metrics

Diatom indices showed small differences over time; however, their high values were indicative of high/good ecological status classes (Table 2). Half of the indices tended to slightly increase over time: IPS, IBD, CEE and IDAP. On the other hand, evenness, diversity, NORTIdiat and TDI tended to decrease slightly. Species richness decreased during the 2nd period, explaining the decrease in diversity (Table 2). Diversity and evenness showed significant differences between periods (Student's $t$ test $P<0.05$; Table 2, Fig. 7). 


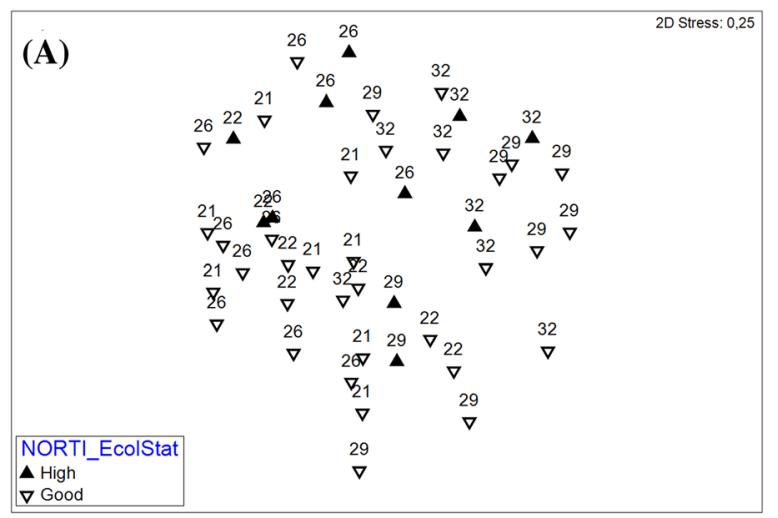

Fig. 6 Non-metric MultiDimensional Scaling (nMDS) analysis of benthic diatom samples. Symbols represent the ecological status calculated with (A) the NORTIdiat index and (B) the IPS.

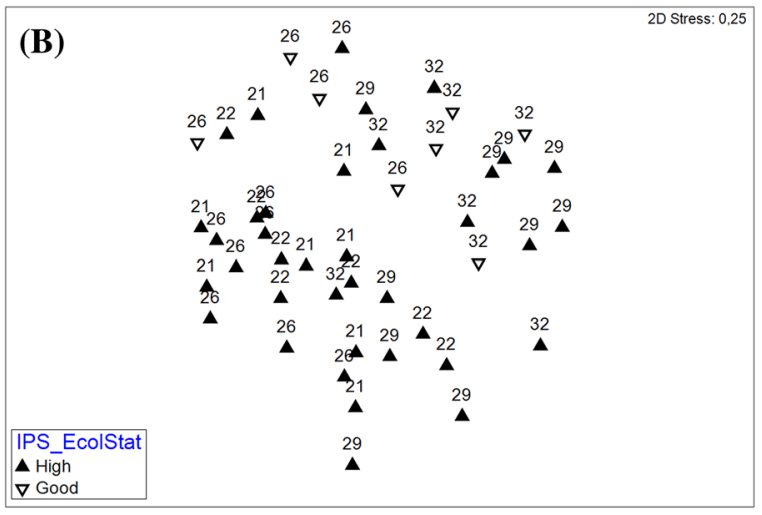

Bray-Curtis distance, stress 0.25 . Labels represent the rivers types according to the Spanish typology
Table 2 Average and standard error (SE) of the most common diatom indices for the 1 st and 2 nd study periods. $P$-value of the Student's $t$ test between periods

\begin{tabular}{lccc}
\hline Metrics & Mean \pm SE 1st period & Mean \pm SE 2nd period & $P$-value \\
\hline RICHNESS & $21.8 \pm 1.3$ & $18.8 \pm 1.2$ & 0.106 \\
DIVERSITY & $2.9 \pm 0.1$ & $2.4 \pm 0.1$ & $0.010^{*}$ \\
EVENNESS & $0.66 \pm 0.02$ & $0.55 \pm 0.03$ & $0.030^{*}$ \\
NORTIdiat & $0.868 \pm 0.024$ & $0.842 \pm 0.025$ & 0.439 \\
IPS & $16.9 \pm 0.2$ & $17.8 \pm 0.5$ & 0.119 \\
IBD & $18.8 \pm 0.2$ & $19.5 \pm 0.4$ & 0.147 \\
CEE & $17.1 \pm 0.2$ & $17.9 \pm 0.4$ & 0.116 \\
IDAP & $14.8 \pm 0.4$ & $16.2 \pm 0.6$ & 0.064 \\
TDI & $64.1 \pm 1.5$ & $63.6 \pm 2.1$ & 0.845 \\
\hline
\end{tabular}

*Significant at $P<0.05$

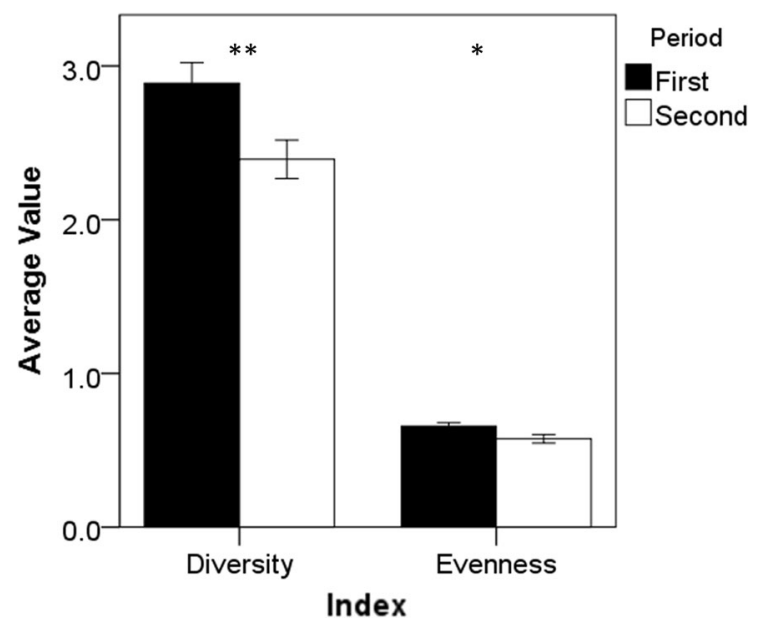

Fig. 7 Average and standard error (SE) of diatom indices that had significant differences between periods. Test with * significant at the 0.05 level and $* *$ at the 0.01 level. Error bars represent $\pm 1 \mathrm{SE}$

\section{Discussion}

Our comparative analyses of diatom assemblages between two periods spanning 17 years in nonsignificantly impaired streams demonstrate a general persistence of diatom composition in Picos de Europa National Park. The characteristic species of the rivertype community and the high/good ecological status were maintained over time and the observed variations in their proportions should be attributed to the general maintenance or even improvement of the stream's environmental conditions. This study demonstrates that analysis of data collected during different periods can be successfully applied to support conservation and assess management strategies under changing European climates. 
Temporal variation in water chemistry

Stream water composition resulted in slight, although important, variations in conductivity and nutrient contents. Electrolytic conductivity records are typical of non-impaired calcareous headwaters in North Spain during low flow periods in summer (Martínez et al., 2015; Pardo et al., 2018). The pH levels increased significantly, although they always remained within the range of calcareous streams (Corman et al., 2016). The results of the dbRDA revealed that period and EC were found to have the greatest explanatory power for diatom species distribution. However, no significant differences were found amongst diatom assemblages between periods. EC has already been found as the most influential environmental variable for diatom species (Pajunen et al., 2020). This study area presented a lower nutrient content than other calcareous geographical regions (Poikane et al., 2019). In areas with higher nutrient content, nutrients were the most important variables to explain the variation in the diatom species composition (González-Paz et al., 2020). Even though evidencing small decreases with time that should be attributed to a general improvement of water quality due to implemented good practices since 2012 within the natural park aiming to reduce the impact from agriculture and livestock activities. Moreover, these mountain streams have well-oxygenated waters. The observed significantly decrease in nutrients between periods clearly points to diffuse reduction in nutrient inputs. Higher $\mathrm{N}_{-} \mathrm{NO}_{3}{ }^{-}$ and $\mathrm{P}_{-} \mathrm{PO}_{4}{ }^{3-}$ in streams in the 1 st period may be due to the agricultural expansion and aggregation detected between 2006 and 2012 in the Cantabrian Mountains (García-Llamas et al., 2019), as agricultural and breeding activities are the main source for $\mathrm{N}_{-} \mathrm{NO}_{3}{ }^{-}$ contents (Carayon et al., 2019; Gaglioti et al., 2019). However, the reduction in agricultural activity in the Cantabrian Mountains has caused land abandonment since 2015 (Perpiña-Castillo et al., 2020) seeming to coincide in time with lower $\mathrm{N}_{-} \mathrm{NO}_{3}{ }^{-}$contents during the 2 nd period of study. Our information on land-use indicated that all the studied sites have between 85 and $100 \%$ natural and semi-natural areas and between 0 and $15 \%$ agricultural areas. Recent studies in this area suggest that this trend of reduction of agricultural area will continue in the coming decades, reducing by $14.5 \%$ by the year 2049 with respect to the year 1989 (Hernández-Romero, 2020). Furthermore, the area most affected by livestock in the surroundings of the study area (Cabrales municipality) began to apply best practices in 2012 .

Temporal changes in diatom assemblages

Diatom assemblages were stable as they persisted over time because we did not detect significant changes in their composition between the two periods. The most abundant species in the two studied basins, Achnanthidium pyrenaicum, Achnanthidium minutissimum and Cocconeis euglypta, are characteristic of calcareous rivers (Beltrami et al., 2012; Leira et al., 2017). The most abundant species in this study area together with Gomphonema pumilum (Grunow) E.Reichardt \& Lange-Bertalot and Navicula tripunctata (O.F.Müller) Bory constitute the most abundant species of the specific biological reference community for type 1 of Mountain calcareous rivers, according to the NORTIdiat classification (Pardo et al., 2018). Both Achnanthidium minutissimum and Achnanthidium pyrenaicum have been found as dominant species in other temperate high mountain protected areas (e.g. Peszek et al., 2021; Poland et al., 2016). Cocconeis lineata, Nitzschia fonticola and Navicula cryptotenella significantly reduced their abundance in the 2nd period in the samples classified as good ecological status, whilst Achnanthidium pyrenaicum increased it. Nevertheless, all of them were part of the dominant species throughout the study. Achnanthidium minutissimum has been considered a very cosmopolitan taxon (Taylor et al., 2007) being dominant in a wide range of calcareous (e.g. France; Rimet et al., 2004) and siliceous geologies (e.g. Italy; Bona et al., 2007). Despite this, it is considered indicator of good water quality (Leira et al., 2017) across Atlantic and Mediterranean basins (Almeida et al., 2014; Martín et al., 2010) and of high ecological status in the IPS index (Lecointe et al., 1993). Moreover, it has been found to be of "reference" assemblages (Cantonati et al., 2020; Kelly et al., 2008). Nonetheless, Achnanthidium pyrenaicum is more sensitive than Achnanthidium minutissimum, regarding organic contamination, metals and other pollutants, because of its more specific alkaliphilus character (Cantonati et al., 2014). It should be noted that Achnanthidium minutissimum abundance during the first sampling year (2003) may be biased because Achnanthidium atomoides was not described (Monnier et al., 2004) 
and until then the latter species abundances were attributed to the very similar Achnanthidium minutissimum. However, Achnanthidium atomoides was not very abundant during the first period. A. atomoides has been found together with Cocconeis euglypta, both species related with high phosphate values (Beltrami et al., 2012). This preference could explain the observed reduction in the abundance of Cocconeis euglypta coinciding with $\mathrm{P}_{-} \mathrm{PO}_{4}{ }^{3-}$ decrease during the 2nd period. This species, together with Achnanthidium minutissimum, has been found amongst the most abundance species in the Cyprus stream reference community (Cantonati et al., 2020), in Luxembourg headwaters (Rimet et al., 2004) and in other small mountain streams from the Iberian Peninsula (Gomà et al., 2005; Novais et al., 2020). Nitzschia fonticola, one of the most abundant species during the 1st period, that tends to positively respond to nutrient enrichment (Cochero et al., 2015), decreased with time suggesting a less favourable environmental conditions for the species.

On the other hand, in this study we only found the invasive species Didymosphenia geminata (Lyngbye) M. Schmidt (RD 630/2013) in one sample from one of the streams outside the park (SE012 in 2018) where its abundance represented $1.4 \%$ of the total. This invasive species is native to northern parts of Asia, Europe and North America (Anderson et al., 2020). The species is distributed in several rivers in Northern Spain since 2011 (Ladrera et al., 2018), but it was absent from the studied rivers during the 1 st period studied in the Cantabrian Mountains. The species can be a threat for the biotic diversity of aquatic ecosystems and has to be controlled in its dispersion. The persistence of diatom assemblages between periods confirms our predictions that headwaters located in well-protected natural areas are appropriate systems to be considered reference ecosystems with type specific biological communities.

\section{Differences amongst river types}

Our results show that studied rivers present a great spatial similarity in diatom composition confirming the existence of a single diatom assemblage, thus corresponding to a single river type, the mountainous calcareous river (Pardo et al., 2018). PERMANOVA analyses confirmed the absence of statistically significant differences amongst the diatom assemblages from the different types. In conclusion, the NORTIdiat typology seems to be a more precise method to define river types in the area, as the other Spanish types did not show differences in their species composition, confirming the existence of a homogeneous diatom assemblage in the area. These results reinforce the prediction that river types based on biological reference conditions (i.e. invertebrates or diatom assemblages) are more reliable in Northern Spain than river types derived solely with physiographic descriptors. Therefore, determining the biological communities inhabiting under reference conditions is of great importance to provide more robust ecological status assessments in the future (Stubbington et al., 2017).

Temporal variation in structural metrics

This study was conducted in mountain streams in Northern Spain belonging to a protected area of high ecological value (Barquín et al., 2015) and this was reflected in high values for all community structural metrics that indicate a high/good ecological status, as for other protected mountain areas in Europe (Falasco \& Bona, 2011; Falasco et al., 2012). On the other hand, a significant reduction in diversity and evenness was observed. The decrease in species richness and diversity was attributed to a $30 \%$ species disappearance that corresponded to species of the genus Nitzschia during the 2nd period. Most of the valves belonging to this genus were found in samples classified as good ecological status and a few were found under high ecological status class. The genus Nitzschia is considered tolerant to pollution (Hill et al., 2001), thus its disappearance should be related to a significant improvement in diatomological indices and thus in water quality. The IPS high values throughout both periods correspond to high ecological status (RD $817 / 2015)$ probably related to the reduction of nutrients that reduced the occurrence of Nitzschia species. Slight increases in IDAP index may be related to the decrease of $\mathrm{NO}_{3}{ }^{-}$, since it assesses micro-pollutants and organic contamination based on ammonium and nitrogen (Prygiel et al., 1996). TDI values were high compared to other protected areas (Jüttner et al., 2003; Tang et al., 2006). As it has been found that TDI values are positively correlated with phosphate contents (Jüttner et al., 2003), the decrease in this index during the 2nd period could be related to the decrease in P_PO ${ }_{4}{ }^{3-}$ contents. The NORTIdiat index showed slight non-significant reduction over time. This should 
be attributed to the natural variation in the diatom community at non-impaired sites, as the method uses the whole diatom assemblage to assess changes, being less sensitive to few species additions or absences.

\section{Conclusion}

Although, climate change has caused a rise in temperatures and fewer rainy days throughout the planet, affecting different ecosystems and reducing diversity, protected areas can act as natural reserves recovering degraded habitats and safeguarding intact ecosystems. The diatom assemblages found in these mountain streams persisted over time (2003-2008; 2016-2020) and maintained the high and good ecological status. Best agricultural practices seem to have reduced $\mathrm{N}_{-} \mathrm{NO}_{3}{ }^{-}$and $\mathrm{P}_{-} \mathrm{PO}_{4}{ }^{3-}$ content along the years, further improving water quality. Even though there was a significant reduction in diversity and evenness over time, when comparing the diatom assemblages during two periods, it was observed that dominant species for both periods corresponded to the previously established reference diatom community for this area. This should be contemplated as an indicator of biodiversity maintenance, reflecting that those natural-protected areas have proven to be good biodiversity reservoirs and that headwaters maintain WFD requirements to be considered reference sites. Thus, further studies should address whether the relationship between changes in diatom assemblages and climate change is species-specific, rather than resulting in total assemblage change, as our results point out.

Acknowledgements We want to thank Agustín Monteoliva and Ecohydros S.L. team for their hard work and effort in fieldwork and to the Cantabrian Hydrographic Confederation for the data provided. We also thank two reviewers for their many insightful comments, which have greatly improved this paper.

Author Contributions Conceptualization: CD, IP and JB; Methodology: LG-P, CD, M-C; Software, LG-P, CD and IP; Validation: all authors; Formal Analysis: all authors; Investigation: LG-P and CD; Resources: all authors; Data Curation: LG-P, CD and IP; Writing - Original Draft Preparation: LG-P, CD and IP; Writing - Review \& Editing: all authors; Visualisation: all authors; Supervision: CD, IP, JB and AGV; Project Administration: none; Funding Acquisition: none.
Funding Open Access funding provided thanks to the CRUECSIC and Universidade de Vigo/CISUG agreement with Springer Nature. Cristina Delgado's contribution was financed by the I2C-B postdoctoral grant (2018) from the government of the Xunta de Galicia (Galicia, Spain) and University of Vigo (2020).

\section{Declarations}

Conflict of interest The authors declare that there are no conflict of interest.

Data availability The data sets generated during and/or analysed during the current study will be provided by the corresponding author upon the request of the editor or reviewers.

Open Access This article is licensed under a Creative Commons Attribution 4.0 International License, which permits use, sharing, adaptation, distribution and reproduction in any medium or format, as long as you give appropriate credit to the original author(s) and the source, provide a link to the Creative Commons licence, and indicate if changes were made. The images or other third party material in this article are included in the article's Creative Commons licence, unless indicated otherwise in a credit line to the material. If material is not included in the article's Creative Commons licence and your intended use is not permitted by statutory regulation or exceeds the permitted use, you will need to obtain permission directly from the copyright holder. To view a copy of this licence, visit http://creativecommons.org/licenses/by/4.0/.

\section{References}

AFNOR NF EN 13946, 2003. Qualité de l'eau -Guide pour l'échantillonnage en routine et le prétraitement des diatomées benthiques de rivières. Norme française.

Akaike, H., 1987. Factor analysis and the AIC. Psychometrika 52: $317-332$.

Almeida, S. F., C. Elias, J. Ferreira, E. Tornés, C. Puccinelli, F. Delmas, G. Dörflinger, G. Urbanič, S. Marcheggiani, J. Rosebery, L. Mancini \& S. Sabater, 2014. Water quality assessment of rivers using diatom metrics across Mediterranean Europe: a methods intercalibration exercise. Science of the Total Environment 476-477: 768-776.

Álvarez-Cabria, M., J. Barquín \& F. J. Peñas, 2016. Modelling the spatial and seasonal variability of water quality for entire river networks: relationships with natural and anthropogenic factors. Science of the Total Environment 545-546: 152-162.

Álvarez-Cabria, M., A. M. González-Ferreras, F. J. Peñas \& J. Barquín, 2017. Modelling macroinvertebrate and fish biotic indices: from reaches to entire river networks. Science of the Total Environment 577: 308-318.

Anderson, S. E., G. P. Closs \& C. D. Matthaei, 2020. Agricultural land-use legacy, the invasive alga Didymosphenia geminata and invertebrate communities in upland streams 
with natural flow regimes. Environmental Management 65: 804-817.

Anderson, M. J., R. N. Gorley \& K. R. Clarke, 2008. PERMANOVA+ for PRIMER: guide to software and statistical methods. PRIMER-E, Plymouth, UK

Arai, R., K. Nukazawa, S. Kazama \& Y. Takemon, 2015. Variation in benthic invertebrate abundance along thermal gradients within headwater streams of a temperate basin in Japan. Hydrobiologia 762: 1-9.

ARM/2656/2008, Orden del 10 de septiembre, por la que se aprueba la instrucción de planificación hidrológica. Boletín Oficial del Estado (BOE) $n^{\circ} 229$, pp 38472-38582.

Ballesteros, D., E. Fernández-Martínez, L. Carcavilla \& M. Jiménez-Sánchez, 2019. Karst cave geoheritage in protected areas: characterisation and proposals of management of deep caves in the Picos de Europa National Park (Spain). Geoheritage 11: 1919-1939.

Ballesteros, D., A. Álvarez-Vena, M. Monod-Del Dago, L. Rodríguez-Rodríguez, J. Sanjurjo-Sánchez, D. ÁlvarezLao, C. Pérez-Mejías, P. Valenzuela, I. DeFelipe, C. Laplana, H. Cheng \& M. Jiménez-Sánchez, 2020. Paleoenvironmental evolution of Picos de Europa (Spain) during marine isotopic stages $5 \mathrm{c}$ to 3 combining glacial reconstruction, cave sedimentology and paleontological findings. Quaternary Science Reviews 248: 106581.

Barquín, J., F. Peñas, M. Álvarez-Cabria, T. Rodríguez-Castillo, A. González, E. Estévez, M. Lezcano, F. Fernández, J. Rojo, A. García \& C. Álvarez, 2015. Optimización de las redes de seguimiento del estado de conservación en ríos de alta montaña. In Amengual, P. \& B. Asensio (eds), Proyectos de Investigación en Parques Nacionales: 2010-2013 Organismo Autónomo de Parques Nacionales, Madrid: 35-61.

Belmar, O., J. Barquín, J. M. Álvarez-Martínez, F. J. Peñas \& M. Del Jesus, 2016. The role of forest maturity on catchment hydrologic stability. Hydrology and earth system sciences discussions: 1-17.

Beltrami, M. E., F. Ciutti, C. Cappelletti, B. Lösch, R. Alber \& L. Ector, 2012. Diatoms from Alto Adige/Südtirol (Northern Italy): characterization of assemblages and their application for biological quality assessment in the context of the Water Framework Directive. Hydrobiologia 695: 153-170.

Birk, S., W. Bonne, A. Borja, S. Brucet, A. Courrat, S. Poikane, W. van de Bund, N. Zampoukas \& D. Hering, 2012. Three hundred ways to assess Europe's surface waters: an almost complete overview of biological methods to implement the Water Framework Directive. Ecological Indicators 18: $31-41$.

Bona, F., E. Falasco, S. Fassina, B. Griselli \& G. Badino, 2007. Characterization of diatom assemblages in mid-altitude streams of NW Italy. Hydrobiologia 583: 265-274.

Bossard, M., J. Feranec \& J. Otahel, 2000. CORINE Land Cover Technical Guide. Addendum 2000. European Environment Agency, Copenhagen, p. 105.

Burliga, A. L. \& J. P. Kociolek, 2016. Diatoms (Bacillariophyta) in Rivers. In: Necchi, O. Jr., (ed), River Algae. Springer Nature: Cham, Switzerland: 73-128.

Caissie, D., 2006. The thermal regime of rivers: a review. Freshwater Biology 51(8): 1389-1406.
Canseco, V. G. \& N. Heredia, 2003. Parque Nacional de los Picos de Europa. Canseco editores. ISBN; 8493209589.

Cantonati, M., N. Angeli, L. Virtanen, A. Z. Wojtal, J. Gabrieli, E. Falasco, I. Lavoie, S. Morin, A. Marchetto, C. Fortin \& S. Smirnova, 2014. Achnanthidium minutissimum (Bacillariophyta) valve deformities as indicators of metal enrichment in diverse widely-distributed freshwater habitats. Science of the Total Environment 475: 201-215.

Cantonati, M., M. G. Kelly, D. Demartini, N. Angeli, G. Dörflinger, A. Papatheodoulou \& D. G. Armanini, 2020. Overwhelming role of hydrology-related variables and river types in driving diatom species distribution and community assemblage in streams in Cyprus. Ecological Indicators 117: 106690.

Carayon, D., J. Tison-Rosebery \& F. Delmas, 2019. Defining a new autoecological trait matrix for French stream benthic diatoms. Ecological Indicators 103: 650-658.

CEDEX, 2018a. Estación 1295: Río Sella en Cangas De Onis. https://ceh.cedex.es/anuarioaforos/afo/estaf-datos. asp? indroea $=1295$

CEDEX, 2018b. Estación 1268: Río Deva en Puentelles. https:// ceh.cedex.es/anuarioaforos/afo/estaf-datos.asp?indroea= 1268

Cemagref, 1982. Etude des Méthodes Biologiques d'Appréciation Quantitative de la Qualité des Eaux. Rapport Q. E. Lyon: Agence de 'Eau Rhône-Méditerranée-Corse' Cemagref.

CEN (Comité Europeén de Normalisation), 2004. Water quality: guidance standard for the identification, enumeration and interpretation of benthic diatom samples from running waters EN14407, EN 14407.

Clarke, K. R. \& R. N. Gorley, 2015. PRIMER v7: User Manual/ Tutorial. PRIMER-E. Plymouth, United Kingdom.

Cochero, J., M. Licursi \& N. Gómez, 2015. Changes in the epipelic diatom assemblage in nutrient rich streams due to the variations of simultaneous stressors. Limnologica 51: 15-23.

Corman, J. R., E. K. Moody \& J. J. Elser, 2016. Calcium carbonate deposition drives nutrient cycling in a calcareous headwater stream. Ecological Monographs 86: 448-461.

Cruz, J. V., D. Pacheco, R. Cymbron \& S. Mendes, 2010. Monitoring the groundwater chemical status in the Azores archipelago (Portugal) in the context of the EU water framework directive. Environmental Earth Sciences 61: 173-186.

Delgado, C., M. J. Feio, I. Pardo \& S. F. P. Almeida, 2020. Effects of water temperature over benthic diatom communities: insights from thermal springs. Plant Ecology \& Diversity 13: 325-337.

Estevez, E., T. Rodríguez-Castillo, M. Álvarez-Cabria, F. J. Peñas, A. M. González-Ferreras, M. Lezcano \& J. Barquín, 2017. Analysis of structural and functional indicators for assessing the health state of mountain streams. Ecological Indicators 72: 553-564.

European Commission, 2000. Directive 2000/60/EC of the European Parliament and of the Council of 23 of October 2000 establishing a framework for community action in the field of water policy. The Official Journal of the European Union L 327: 1-73. 
Falasco, E. \& F. Bona, 2011. Diatom community biodiversity in an Alpine protected area: a study in the Maritime Alps Natural Park. Journal of Limnology 70: 157-167.

Falasco, E., L. Ector, E. Ciaccio, L. Hoffmann \& F. Bona, 2012. Alpine freshwater ecosystems in a protected area: a source of diatom diversity. Hydrobiologia 695: 233-251.

Felicisimo, A. M. P., 1990. El clima de Asturias. En Enciclopedia temática de Asturias 10 (fasc. 200-202): 179-208. Silverio Cañada Ed. Gijón.

Gaglioti, S., E. Infusino, T. Caloiero, G. Callagari \& I. Guagliardi, 2019. Geochemical characterization of spring waters in the Crati River Basin, Calabria, (Southern Italy). Geofluids. https://doi.org/10.1155/2019/3850148.

García-Llamas, P., I. R. Geijzendorffer, A. P. García-Nieto, L. Calvo, S. Suárez-Seone \& W. Cramer, 2019. Impact of land cover change on ecosystem service supply in mountain systems: a case study in the Cantabrian Mountains (NW of Spain). Regional Environmental Change 19: 529-542.

Gomà, J., F. Rimet, J. Cambra, L. Hoffmann \& L. Ector, 2005. Diatom communities and water quality assessment in mountain rivers of the Upper Segre Basin (La Cerdanya, Oriental Pyrenees). Hydrobiologia 551: 209-225.

González-Paz, L., C. Delgado \& I. Pardo, 2020. Understanding divergences between ecological status classification systems based on diatoms. Science of the Total Environment 734: 139418.

Göthe, E., N. Friberg, M. Kahlert, J. Temnerud \& L. Sandin, 2014. Headwater biodiversity among different levels of stream habitat hierarchy. Biodiversity Conservation 23: 63-80.

Grenyer, R., C. Orme, S. Jackson, G. H. Thomas, R. G. Davies, T. J. Davies, K. E. Jones, V. A. Olson, R. S. Ridgely, P. C. Rasmussen, T. S. Ding, P. M. Bennett, T. M. Blackburn, K. J. Gaston, J. L. Gittleman \& I. P. F. Owens, 2006. Global distribution and conservation of rare and threatened vertebrates. Nature 444: 93-96.

Guiry, M.D. \& G. M. Guiry, 2021. AlgaeBase. World-wide electronic publication, National University of Ireland, Galway. http://www.algaebase.org. Accessed July 26, 2021.

Hering, D., A. Borja, J. I. Jones, D. Pont, P. Boets, A. Bouchez, K. Bruce, S. Drakare, B. Hanfling, M. Kahlert, F. Leese, K. Meissner, P. Mergen, Y. Reyjol, P. Segurado, A. Vogler \& M. Kelly, 2018. Implementation options for DNA based identification into ecological status assessment under the European Water Framework Directive. Water Research 138: 192-205.

Hernández-Romero, G. 2020. Analysis of the effects on change in land use and cover in the provision of ecosystem services: biodiversity, soil erosion and blue and green infrastructure networks in the Cordillera Cantábrica. Master's Thesis. University of Leon, Ponferrada. 66pp.

Hill, B. H., R. J. Stevenson, Y. Pan, A. T. Herlihy, P. R. Kaufmann \& C. B. Johnson, 2001. Comparison of correlations between environmental characteristics and stream diatom assemblages characterized at genus and species levels. Journal of the North American Benthological Society 20: 299-310.

Hlúbiková, D., M. H. Novais, A. Dohet, L. Hoffmann \& L. Ector, 2014. Effect of riparian vegetation on diatom assemblages in headwater streams under different land uses. Science of the Total Environment 475: 234-247.

Jiang, Z., J. Liu, J. Chen, Q. Chen, X. Yan, J. Xuan \& J. Zeng, 2014. Responses of summer phytoplankton community to drastic environmental changes in the Changjiang (Yangtze River) estuary during the past 50 years. Water Research 54: $1-11$.

José Vidal-Macua, J., M. Ninyerola, A. Zabala, C. DomingoMarimon \& X. Pons, 2017. Factors affecting forest dynamics in the Iberian Peninsula from 1987 to 2012. The role of topography and drought. Forest Ecology and Management 406: 290-306.

Jüttner, I., S. Sharma, B. M. Dahal, S. J. Ormerod, P. J. Chimonides \& E. J. Cox, 2003. Diatoms as indicators of stream quality in the Kathmandu Valley and Middle Hills of Nepal and India. Freshwater Biology 48: 2065-2084.

Karaouzas, I., E. Smeti, E. Kalogianni \& NTh. Skoulikidis, 2019. Ecological status monitoring and assessment in Greek rivers: do macroinvertebrate and diatom indices indicate same responses to anthropogenic pressures? Ecological Indicators 101: 126-132.

Kelly, M. G. \& B. A. Whitton, 1995. The Trophic Diatom Index: a new index for monitoring eutrophication in rivers. Journal of Applied Phycology 7: 433-444.

Kelly, M. G., A. Cazaubon, E. Coring, A. Dell'Uomo, L. Ector, B. Goldsmith, H. Guasch, J. Hürlimann, A. Jarlman, B. Kawecka, J. Kwandrans, R. Laugaste, E.-A. Lindstrøm, M. Leitao, P. Marvan, J. Padisák, E. Pipp, J. Prygiel, E. Rott, S. Sabater, H. van Dam \& J. Vizinet, 1998. Recommendations for the routine sampling of diatoms for water quality assessments in Europe. Journal of Applied Phycology 10: $215-224$.

Kelly, M., S. Juggins, R. Guthrie, S. Pritchard, J. Jamieson, B. Rippey, H. Hirst \& M. Yallop, 2008. Assessment of ecological status in U.K. rivers using diatoms. Freshwater Biology 53: 403-422.

Krammer, K., 1997a. Die Cymbelloiden Diatomeen. Teil 1. Allgemeiner Und Encyonema Part. Bibliotheca Diatomologica 36: 1-382.

Krammer, K., 1997b. Die Cymbelloiden Diatomeen. Teil 2. Encyonema part, Encyonopsis und Cymbellopsis. Bibliotheca Diatomologica 37: 1-469.

Krammer, K. \& H. Lange-Bertalot, 1986. 'Bacillariophyceae'. 1. Teil: Naviculaceae, Susswasserflora von Mitteleuropa, Gustav Fischer Verlag, Stuttgart, Band 2-1: 876.

Krammer, K. \& H. Lange-Bertalot, 1988. 'Bacillariophyceae'. 2. Teil: Bacillariaceae, Epithemiaceae, Surirellaceae, Süsswasserflora von Mitteleuropa, Gustav Fischer Verlag, Stuttgart, Band 2-2: 596.

Krammer, K. \& H. Lange-Bertalot, 1991a. 'Bacillariophyceae'. 3. Teil: Centrales, Fragilariaceae, Eunotiaceae. Süsswasserflora von Mitteleuropa, Gustav Fischer Verlag, Stuttgart, Band 2-3: 600.

Krammer, K. \& H. Lange-Bertalot, 1991b. 'Bacillariophyceae'. 4. Teil: Achnanthaceae, Kritische Ergänzungen zu Navicula (Lineolatae) und Gomphonema. Gesamtliteraturverzeichnis, Susswasserflora von Mitteleuropa, Gustav Fischer Verlag, Stuttgart, Band 2-4: 437.

Krammer, K., 2002. Cymbella. In: Lange-Bertalot H (ed) Diatoms of Europe, diatoms of the European inlands waters 
and comparable habitats 3. H, Gantner Verlag ARG, Ruggell KG. pp 584.

Kuglerová, L., E. M. Hasselquist, J. S. Richardson, R. A. Sponseller, D. P. Kreutzweiser \& H. Laudon, 2017. Management perspectives on Aqua incognita: connectivity and cumulative effects of small natural and artificial streams in boreal forests. Hydrological Processes 31: 4238-4244.

Ladrera, R., J. Gomà \& N. Prat, 2018. Effects of Didymosphenia geminata massive growth on stream communities: Smaller organisms and simplified food web structure. PLoS ONE 13: e0193545.

Lange-Bertalot, H. G. Hofmann, M. Werum \& M. Cantonati, 2017. Freshwater Benthic Diatoms of Central Europe. Over 800 common species used in ecological assessment. English edition with updated taxonomy and added species.

Lange-Bertalot, H. \& A. Steindorf, 1996. Rote Liste der limnischen Kieselalgen (Bacillariophyceae) Deutschland. Schriftenreihe Für Vegetationskunde 28: 633-678.

Lange-Bertalot, H., 1993. 85 neue Taxa und über 100 weitere neu definierte Taxa ergänzend zur Süsswasserflora von Mitteleuropa 2/1-4. - Bibliotheca Diatomologica 27: $1-454$.

Lange-Bertalot, H., 2001. Navicula sensu stricto. 10 genera separated from Navicula sensu lato. Frustulia - In: LangeBertalot, H. (ed), Diatoms of Europe 2. Gantner Verlag ARG, Ruggell KG. pp 526.

Lecointe, C. M. Coste \& J. Prygiel, 2003. Omnidia 3.2 Diatom Index Software including diatom database with taxonomic names, reference and codes of 11645 diatom taxa.

Legendre, P. \& M. J. Anderson, 1999. Distance-based redundancy analysis: testing multispecies responses in multifactorial ecological experiments. Ecological Monographs 69: 1-24.

Leira, M., R. Meijide-Failde \& E. Torres, 2017. Diatom communities in thermos-mineral springs of Galicia (NW Spain). Diatom Research 32: 29-42.

Martín, G., J. Toja, S. Sala, M. R. Fernández, I. Reyes \& M. Casco, 2010. Application of diatom biotic indices in the Guadalquivir River Basin, a Mediterranean basin. Which one is the most appropriated? Environmental Monitoring and Assessment 170: 519-534.

Martínez, A., J. Pérez, J. Molinero \& J. Pozo, 2015. Effects of flow scarcity on leaf-litter processing under oceanic climate conditions in calcareous streams. Science of the Total Environment 503-504: 251-257.

McArdle, B. H. \& M. J. Anderson, 2001. Fitting multivariate models to community data: a comment on distance-based redundancy analysis. Ecology (durham) 82: 290-297.

McCune, B. P., J. B. Grace \& D. L. Urban, 2002. Analysis of ecological communities. MjM Software Design, Gleneden Beach, OR.

Meléndez, M., D. Ballesteros \& M. Jiménez-Sánchez, 2019. Hidrogeología del Parque Nacional de los Picos de Europa, norte de España. Boletín Geológico y Minero 130(4): 593-614.

Monnier, O., H. Lange-Bertalot, F. Rimet, L. Hoffmann \& L. Ector, 2004. Achanthidium atomoides sp. nov., a new diatom from the Grand-Duchy of Luxembourg. Vie Milieu 54: $127-136$.
Moore, A. A. \& M. A. Palmer, 2005. Invertebrate biodiversity in agricultural and urban headwater streams: implications for conservation and management. Ecological Applications 15: 1169-1177.

Mortágua, A., V. Vasselon, R. Oliveira, C. Elias, C. Chardon, A. Bouchez, F. Rimet, M. J. Feio \& S. F. P. Almeida, 2019. Applicability of DNA metabarcoding approach in the bioassessment of Portuguese rivers using diatoms. Ecological Indicators 106: 105470.

Nicola, G. G., B. Elvira, B. Jonsson, D. Ayllón \& A. Almodóvar, 2018. Local and global climatic drivers of Atlantic salmon decline in southern Europe. Fisheries Research 198: 78-85.

Noga, T. J., A. Stanek-Tarkowska, N. K. Pajączek \& Ł Peszek, 2014. Ecological assessment of the San River water quality on the area of the San Valley Landscape Park. Journal of Ecological Engineering 15: 12-22.

Noga, T., J. Stanek-Tarkowska, M. Rybak, N. Kochman-Kędziora, Ł Peszek \& A. Pajączek, 2016. Diversity of diatoms in the Natural, Mid-Forest Terebowiec Stream - Bieszczady National Park. Journal of Ecological Engineering 17: 232-247.

Nõges, P., W. Van de Bund, A. Cardoso \& A. Heiskanen, 2007. Impact of climatic variability on parameters used in typology and ecological quality assessment of surface waters-implications on the Water Framework Directive. Hydrobiologia 584: 373-379.

Nõges, P., W. van de Bund, A. C. Cardoso, A. G. Solimini \& A. S. Heiskanen, 2009. Assessment of the ecological status of European surface waters: a work in progress. Hydrobiologia 633: 197-211.

Novais, M. H., E. A. Morales, A. M. Penha, M. Potes, A. Bouchez, A. Barthès, M. J. Costa, R. Salgado, J. Santos \& M. Morais, 2020. Benthic diatom community dynamics in Mediterranean intermittent streams: effects of water availability and their potential as indicators of dry-phase ecological status. Science of the Total Environment 719: 137462

Nukazawa, K. R., S. Kazama. Arai \& Y. Takemon, 2018. Projection of invertebrate populations in the headwater streams of a temperate catchment under a changing climate. Science of the Total Environment 642: 610-618.

Nunes, L., M. Moreno, I. Alberdi, J. G. Alvarez-Gonzalez, P. Godinho-Ferreira, S. Mazzoleni \& F. C. Rego, 2020. Harmonized classification of forest types in the Iberian Peninsula based on national forest inventories. Forests 11: 1.

Pajunen, V., M. Kahlert \& J. Soininen, 2020. Stream diatom assemblages as environmental indicators - A cross-regional assessment. Ecological Indicators 113: 106183.

Pardo, I., C. Gómez-Rodríguez, J. Wasson, R. Owen, W. van de Bund, M. Kelly, C. Bennett, S. Birk, A. Buffagni, S. Erba, N. Mengin, J. Murray-Bligh \& G. Ofenböeck, 2012. The European reference condition concept: a scientific and technical approach to identify minimally-impacted river ecosystems. The Science of the Total Environment 420: 33-42.

Pardo, I., S. Poikane \& W. Bonne, 2011. Revision of the consistency in Reference Criteria application in the phase one of the European Intercalibration Exercise. EUR 24843 EN. Luxembourg (Luxembourg): Publications Office of the European Union; 2011. JRC65230 
Pardo, I., C. Gómez-Rodríguez, R. Abraín, E. García-Roselló \& T. B. Reynoldson, 2014. An invertebrate predictive model (NORTI) for streams and rivers: sensitivity of the model in detecting stress gradients. Ecological Indicators 45: 51-62.

Pardo, I., C. Delgado, R. Abraín, C. Gómez-Rodríguez, E. García-Roselló, L. García \& T. B. Reynoldson, 2018. A predictive diatom-based model to assess the ecological status of streams and rivers of Northern Spain. Ecological Indicators 90: 519-528.

Pawlowski, J., M. Kelly-Quinn, F. Altermatt, L. ApothélozPerret-Gentil, P. Beja, A. Boggero, A. Borja, A. Bouchez, T. Cordier, I. Domaizon, M. J. Feio, A. F. Filipe, R. Fornaroli, W. Graf, J. Herder, B. van der Hoorn, J. I. Jones, M. Sagova-Mareckova, C. Moritz, J. Barquín, J. J. Piggott, M. Pinna, F. Rimet, B. Rinkevich, C. Sousa-Santos, V. Specchia, R. Trobajo, V. Vasselon, S. Vitecek, J. Zimmerman, A. Weigand, F. Leese \& M. Kahlert, 2018. The future of biotic indices in the ecogenomic era: Integrating (e)DNA metabarcoding in biological assessment of aquatic ecosystems. Science of the Total Environment 637-638: 1295-1310.

Pérez, J., A. Basaguren, E. Descals, A. Larrañaga \& J. Pozo, 2013. Leaf-litter processing in headwater streams of northern Iberian Peninsula: moderate levels of eutrophication do not explain breakdown rates. Hydrobiologia 718: 41-57.

Pérez-Sánchez, J., J. Senent-Aparicio, C. M. Santa-María \& A. López-Ballesteros, 2020. Assessment of ecological and hydro-geomorphological alterations under climate change using SWAT and IAHRIS in the Eo river in Northern Spain. Water 12: 1745.

Perpiña-Castillo, C., E. C. Aliaga, C. Lavalle \& J. C. M. Llario, 2020. An assessment and spatial modelling of agricultural land abandonment in Spain (2015-2030). Sustainability 12: 560 .

Peszek, Ł, A. Zgrundo, T. Noga, N. Kochman-Kędziora, A. Poradowska, M. Rybak, C. Puchalski \& J. Lee, 2021. The influence of drought on diatom assemblages in a temperate climate zone: a case study from the Carpathian Mountains, Poland. Ecological Indicators 125: 107579.

Peterson, B. J., W. M. Wollheim, P. J. Mulholland, J. R. Webster, J. L. Meyer, J. L. Tank, E. Martí, W. B. Bowden, H. M. Valett, A. E. Hershey, W. H. McDowell, W. K. Dodds, S. K. Hamilton, S. Gregory \& D. D. Morrall, 2001. Control of nitrogen export from watersheds by headwater streams. Science 292: 86-90.

Poikane, S., M. G. Kelly, F. Salas Herrero, J. Pitt, H. P. Jarvie, U. Claussen, W. Leujak, A. Lyche Solheim, H. Teixeira \& G. Phillips, 2019. Nutrient criteria for surface waters under the European Water Framework Directive: current state-ofthe-art, challenges and future outlook. Science of the Total Environment 695: 133888.

Polmear, R., J. S. Stark, D. Roberts \& A. McMinn, 2015. The effects of oil pollution on Antarctic benthic diatom communities over 5 years. Marine Pollution Bulletin 90(1-2): $33-40$.

Prince, H. E., R. G. H. Bunce \& R. H. G. Jongman, 2012. Changes in the vegetation composition of hay meadows between 1993 and 2009 in the Picos de Europa and implications for nature conservation. Journal for Nature Conservation 20: 162-169.
Prygiel, J. M. \& Coste, 2000. Guide méthodologique pour la mise en œuvre de l'Indice Biologique Diatomées. NF T90-394. Agence de L'Eau Artois-Picardie, Cemagref Groupement de Bordeaux: pp 134.

Prygiel, J., L. Lévêque \& R. Iserentant, 1996. Un nouvel indice diatomique pratique pour l'évaluation de la qualité des eaux en réseau de surveillance. Revue Des Sciences De L'eau 9: 97-113.

QGIS Development Team, 2020. QGIS Geographic Information System. Open Source Geospatial Foundation Project. http://qgis.osgeo.org. Accessed 29 October 2020.

Raimonet, M., V. Thieu, M. Silvestre, L. Oudin, C. Rabouille, R. Vautard \& J. Garnier, 2018. Landward perspective of coastal eutrophication potential under future climate change: the Seine river case (France). Frontiers in Marine Science 5: 136.

Real Decreto, RD 630/2013, de 2 de agosto, por el que se regula el Catálogo español de especies exóticas invasoras.

Real Decreto, RD 817/2015, 11 de septiembre, por el que se establecen los criterios de seguimiento y evaluación del estado de las aguas superficiales y las normas de calidad ambiental. Boletín Oficial del Estado (BOE) n ${ }^{\circ} 219$, pp. 80582-80677.

Rimet, F., L. Ector, H. M. Cauchie \& L. Hoffmann, 2004. Regional distribution of diatom assemblages in the headwater streams of Luxembourg. Hydrobiologia 520: 105-117.

Rodríguez-Castillo, T., E. Estévez, A. M. González-Ferreras \& J. Barquín, 2019. Estimating ecosystem metabolism to entire river networks. Ecosystems 22: 892-911.

Rott, E., M. Cantonati, L. Füreder \& P. Pfister, 2006. Benthic algae in high altitude streams of the Alps - a neglected component of the aquatic biota. Hydrobiologia 562: 195-216.

Sánchez-Montoya, M. M., M. I. Arce, M. R. Vidal-Abarca, n Suárez, N. Prat \& R. Gómez, 2012. Establishing physicochemical reference conditions in Mediterranean streams according to the European Water Framework Directive. Water Research 46(7): 2257-2269.

Schlüter, M. H., A. Kraberg \& K. H. Wiltshire, 2012. Long-term changes in the seasonality of selected diatoms related to grazers and environmental conditions. Journal of Sea Research 67: 91-97.

Selby, D. A., J. M. Ihnat \& J. J. Messer, 1985. Effects of subacute cadmium exposure on a hardwater mountain stream microcosm. Water Research (oxford) 19: 645-655.

Senent-Aparicio, J., J. Pérez-Sánchez, J. Carrillo-García \& J. Soto, 2017. Using SWAT and fuzzy TOPSIS to assess the impact of climate change in the headwaters of the Segura River Basin (SE Spain). Water (basel) 9: 149.

Serrano, E., J. J. González-Trueba, J. J. Sanjosé \& L. M. Del Río, 2011. Ice patch origin, evolution and dynamics in a temperate high mountain environment: the Jou Negro, Picos de Europa (NW Spain). Geografiska annaler. Series a, Physical Geography 93: 57-70.

Stoddard, J. L., D. P. Larse, C. P. Hawkins, R. K. Johnson \& R. H. Norris, 2006. Setting expectations for the ecological conditions of streams: the concept of reference condition. Ecological Applications 16(4): 1267-1276.

Stubbington, R., J. England, P. J. Wood \& C. E. M. Sefton, 2017. Temporary streams in temperate zones: recognizing, 
monitoring and restoring transitional aquatic-terrestrial ecosystems. Wiley Interdisciplinary Reviews, Water 4: e1223.

Tang, T., Q. Cai \& J. Liu, 2006. Using epilithic diatom communities to assess ecological condition of Xiangxi River system. Environmental Monitoring and Assessment 112: 347-361.

Taylor, J. C., J. Prygiel, A. Vosloo \& P. A. de la Rey, 2007. Can diatom-based pollution indices be used for biomonitoring in South Africa? A case study of the Crocodile West and Marico water management area. Hydrobiologia 592: 455-464.

Trobajo, R., L. Rovira, L. Ector, C. E. Wetzel, M. Kelly \& D. G. Mann, 2013. Morphology and identity of some ecologically important small Nitzschia species. Diatom Research 28(1): 37-59.

Wetzel, C. E., L. Ector, B. Van der Vijver, P. Compère \& D. G. Mann, 2015. Morphology, typification and critical analysis of some ecologically important small naviculoid species (Bacillariophyta). Fottea, Olomouc 15(2): 203-234.

Publisher's Note Springer Nature remains neutral with regard to jurisdictional claims in published maps and institutional affiliations. 